\title{
ANALISA PERBANDINGAN PEMODELAN BASIS DATA MENGGUNAKAN ER- DIAGRAM DAN EER-DIAGRAM PADA KASUS SISTEM ASISTENSI PERKULIAHAN PRAKTIKUM
}

\author{
Eko Darmanto \\ Fakultas Teknik, Program Studi Sistem Informasi \\ Universitas Muria Kudus \\ Email: eko.darmanto@umk.ac.id
}

\begin{abstract}
ABSTRAK
Perselisihan dan kebingungan dalam pemilihan dan penentuan alat pemodelan data secara konseptual sering terjadi apabila tidak memiliki dasar dalam sudut pandang tentang bagaimana penerapan hasil dari pemodelan basis data. Penerapan hasil rancangan basis data diimplementasikan dengan suatu bahasa pemrograman dengan sudut pandang berorientasi pada objek dan tidak berorientasi pada objek. Alat perancangan secara konseptual yang berupa Entity Relationships Diagram (ER-D) dianggap memiliki sudut pandang tidak berorientasi pada objek sedangkan Enhanced Entity Relationships Diagram (EER-D) memiliki pendekatan-pendekatan berorientasi pada objek. EER-D merupakan perluasan dari ER-D dengan adanya tambahan fitur berupa generalisasi, spesialisasi dan kategorisasi. Pada studi kasus sistem asistensi perkuliahan praktikum yang dilakukan dengan pemodelan data dengan merancang basis data menggunakan ER-D dan EER-D dapat dibandingkan bahwa ER-D memiliki kelebihan dalam kesederhanaan notasi, sifatnya umum tetapi sulit diimplementasikan pada kasus yang orientasinya pada objek. EER-D memiliki keunggulan lebih mendekati pada kasus yang ada di lapangan karena berorientasi pada objek, tetapi karena sifatnya yang harus diselesaikan perkasus memaksa perancangannya lebih rumit dan harus rinci. Pada studi kasus sistem asistensi mata kuliah praktikum ini hasil skema relasi yang ditransformasikan dari EER-D lebih banyak dibandingkan dengan menggunakan ER-D. Hasil dari skema relasional ini dapat diterapkan ke dalam aplikasi sistem manajemen basis data diberubah dulu menjadi struktur tabel yang disimpan dalam sebuah basis data.
\end{abstract}

Kata kunci: ER-Diagram, EER-Diagram, analisa perbandingan.

\section{ABSTRACT}

Disputes and confusion in selecting a data modeling tool conceptually often occurs if it has no basis in viewpoint on how application of the results of database modeling. Implementation of the design database is implemented with a programming language with object-oriented viewpoint and not object-oriented. Conceptual design tools in the form of Entity Relationships Diagram (ER-D) is consider of discount viewpoint is not objectoriented, while the Enhanced Entity Relationships Diagram (EER-D) is oriented approaches to the object. EER-D is an extension of the ERD with additional features such generalization, specialization and categorization. In a case study lectures practical assistance system is done with data modeling to design a database using the ER-D and EER-D can be compared to that ER-D has advantages in simplicity of notation, is general in nature but difficult to implement in the case of the orientation of the object. In a case study practicum courses assistance system is the result of the relation scheme that transformed from EER-D more than the use of ER-D. Result of the relational scheme went implemented into the applications database management systems must be change to the structure of a table stored in a database.

Keywords: ER-Diagram, EER-Diagram, compare analysis.

\section{PENDAHULUAN}

Perkuliahan merupakan interaksi antara pengajar (dosen) dengan yang diajar (mahasiswa). Jenis perkuliahan secara umum dilakukan dengan pendekatan praktek dan teori. Pendekatan secara praktek dilakukan di dalam laboratorium yang disebut dengan praktikum. Kegiatan proses belajar mengajar (PBM) untuk kategori praktikum melibatkan dosen pengampu matakuliah, laboran, mahasiswa (praktikan) dan asisten dosen. Laboran adalah seseorang yang bekerja dalam laboratorium [1]. Dalam sebuah laboratorium selain ada laboran, terdapat juga teknisi dan analis. Pada saat proses PBM mata kuliah praktek, di dalam laboratorium terdapat dosen, praktikan, laboran dan asisten dosen. Laboran dan asistem dosen memiliki tugas yang sangat berbeda.

Laboran memiliki tugas membantu aktivitas mahasiswa di laboratorium (indoor atau out door) dalam melakukan suatu kegiatan pendidikan dan penelitian. Kegiatan penelitian dapat dilakukan dalam bentuk proses PBM maupun mandiri (tanpa didampingi dosen). Dalam melakukan tugasnya, seorang Laboran bertanggung jawab dalam menyediakan peralatan yang diperlukan untuk kegiatan praktikum (praktek kerja) dan/atau penelitian serta 
mengembalikan peralatan tersebut ke tempat semula, merapikan dan membersihkan area kerja setelah kegiatan selesai dilakukan [2]. Asisten dosen memiliki tugas mendampingi dosen dalam penyampaian mata kuliah pada proses PBM yang sesuai dengan pokok bahasan dan bidang keahlian dosen. Asisten dosen umumnya tidak bertanggung jawab pada kondisi dan kesiapan laboratium untuk praktikum.

Setiap pelaku dan objek-objek dalam kegiatan perkuliahan praktikum merupakan entitas yang dijadikan dasar untuk pemodelan data. Tujuan dari pemodelan data adalah untuk perancangan basis data yang baik. Keuntungan basis data yang baik yaitu struktur basis data lebih kompak, tabel dan relasinya mudah ditelusur, struktur masingmasing tabel yang lebih efisien dan sistematis, lebih efisien media penyimpanan sekunder untuk transmisi data, tidak ada ambiguitas data dalam semua tabel dan redudansi lebih optimal meskipun dalam database relasional redudansi tidak dapat dihilangkan [3].

Pemodelan data dapat dilakukan dengan berbagai macam cara atau alat pemodelan. Saat ini alat pemodelan data yang sering digunakan adalah Entity Relationships Diagram (ER-D) dan Enhanced Entity Relationships Diagram (EER-D). ER-D pada awalnya diperkenalkan oleh Chen dengan meniru prinsip-prinsip pembentukan simbol-simbol secara alami seperti halnya pembentukan aksara pada tulisan China [4]. Seiring dengan perkembangan pemrograman, alat pemodelan data juga ikut berkembang. Pada awalnya alat pemodelan data menganut prinsip-prinsip relasional tetapi saat ini sudah tidak lagi harus mengacu pada prinsip-prinsip ini sehingga sering disebut dengan pemodelan data non-relasional [3] Pemodelan data non-relasional diterapkan pada pemrograman berorientasi objek. Pemodelan data non-relasional yang mengiringi pemrograman berorientasi pada objek tetapi masih memiliki karakteristik pada ER-D maka munculah EER-D yang menjawab permasalahan ini.

Kebingungan yang terjadi antara pilihan pemodelan data menggunakan ER-D dan EER-D dapat dijelaskan menggunakan perbandingan antara ER-D dan EER-D dengan sebuah studi kasus. Studi kasus yang digunakan adalah sistem asistensi perkuliahan praktikum yang didalamnya akan diuraikan menggunakan diagram, dijelaskan secara naratif dan menggunakan skema relasional sebagai hasil transformasi relasional diagram menjadi skema basis data yang siap diimplementasikan ke dalam sebuah aplikasi manajemen basis data.

\section{METODOLOGI PENELITIAN}

Langkah-langkah penelitian yang dilakukan meliputi: (1) kelayakan dan pendalaman kasus, (2) kajian teoriteori terkait, (3) analisa dan perbandingan model, (4) penyimpulan hasil. Pada tahap (1) kelayakan dan pendalaman kasus, meliputi pengangkatan kasus yang layak digunakan dalam penelitian, menemukan permasalahan, menentukan tujuan dan manfaat. Tahap (2) kajian teori-teori terkait meliputi tinjauan penelitian terdahulu yang berupa jurnal dan artikel serta dari sumber buku referensi. Dasar teori yang digunakan adalah tentang perancangan basis data berorientasi pada objek dan yang tidak berorientasi pada objek, menentukan alat perancangan secara konseptual yang sepadan dengan teori object oriented dan non-object oriented. Tahap (3) dilakukan analisa dari dua alat perancangan basis data secara konseptual yang disesuaikan dengan studi kasus yang diangkat, dan membandingkan hasilnya secara naratif dan implementatif. Tahap (4) menyimpulkan hasil yang diperoleh dari analisa dan perbandingan dari kedua model. Pada tahap (2) dibahas secara rinci pada sub bab berikut.

\subsection{Model Data dan Model Basis Data}

Model data adalah kumpulan dari peralatan-peralatan konseptual yang digunakan untuk menggambarkan data dan hubungan antar data. Model basis data menunjukkan suatu cara/mekanisme yang digunakan untuk mengelola/mengorganisasi data yang berdampak pada bagaimana cara mengelompokkan dan membentuk keseluruhan data yang terkait dalam suatu sistem basis data [5]. Model basis data relasional sebagai model basis data sihingga model basis data relasional sering juga disebut dengan Model Relasional atau Basis Data Relasional [3] [6] [7]. Model konseptual memiliki komponen utama yaitu: entity, relationship, dan attribute [8]. Demikian juga [3] [5] [6] menambahkan model ini dapat disajikan dalam bentuk diagram relasional yang sering disebut dengan Entity Relationship Diagram (ER-D).

Pada model relational, basis data berbentuk tabel 2 dimensi. Tiap tabel terdiri atas lajur mendatar yang disebut dengan baris data (Row/Record), dan lajur vertikal disebut dengan kolom (column/field). Pertemuan antara kolom dan baris merupakan tempat satuan data terkecil (Data Item). Istilah lain dari kolom adalah atribut. Sedangkan basis data relasional merupakan basis data yang terdiri atas sejumlah tabel yang saling berhubungan dalam suatu aplikasi DBMS (Database Mangement Systems) [9].

\subsection{Entity Relationships Diagram (ER-D)}

Pemodelan data dalam bentuk relasional pada awalnya digambarkan dengan pendekatan mirip dengan tata cara pembuatan tulisan dalam bahasa China. Diamana entitas, relasional dan atributnya digambarkan menggunakan notasi dasar persegi panjang, belah ketupat dan lingkaran atau elips. Cara penggambaran dengan notasi ini (Gambar 1) disebut dengan model Chen [4]. 

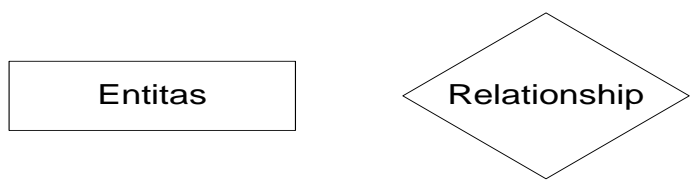

Attribute

\section{Gambar 10. Notasi komponen-komponen konseptual ER-D}

Berdasarkan Gambar 1, terdapat beberapa tata cara penamaan dari entitas, relasi dan atribut. Entitas (entity) adalah "sesuatu" atau "object" dalam dunia nyata yang bisa dibedakan dari semua objects lain [7]. Penamaan entitas diharuskan menggunakan kata benda, sedangkan relasi menggunakan kata kerja. Atribut merupakan karakteristik yang dimemiliki oleh entitas atau relasi. Pada awalnya, atribut berupa sifat-sifat diskriptif yang dipunyai oleh masing-masing anggota dari himpunan entitas [7]. Pada perkembangannya relasi juga dimungkinkan muncul suatu atribut [3] [6]. Gambar 2 merupakan contoh penggambaran ER-D sederhana.
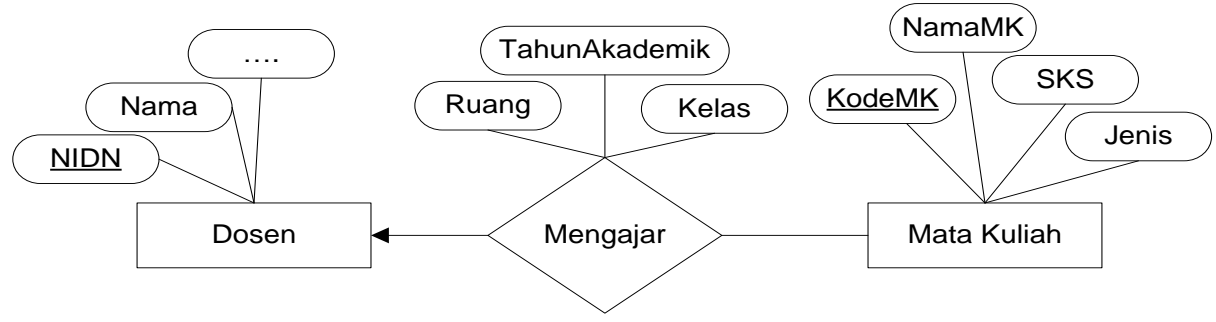

Gambar 2. ER-D sederhana dengan 2 entitas

Berdasarkan Gambar 2, dapat dijelaskan bahwa terdapat atribut dengan nama yang digarisbawahi adalah atribut sebagai kunci utama (primary key-PK). Garis penghubung antar entitas yang melalui relasi yang memiliki tanda panah dan pada sisi lain tidak ada tanda panah maka disebut dengan relasi one-to-many (1-to-m). Hubungan 1-to-m memiliki pengertian bahwa setiap satu data dari entitas tersebut dapat berhubungan dengan banyak data dari entitas lain, dengan kata lain, seorang dosen dapat mengajar banyak mata kuliah dengan beberapa ruang dan kelas paralel dalam satu tahun akademik.

Urutan perancangan basis data menggunakan ER-D memiliki tahapan yaitu; 1). menentukan entitas, 2). menentukan PK, 3). menentukan relasional, 4). menentukan jumlah keterhubungan antar entitas (cardinality constraint), dan 5). melengkapi atribut [9]. Setelah ER-D lengkap terbentuk langkah selanjutnya adalah transformasi atau pemetaan dari ER-D menjadi skema relasional [7].

\subsection{Enhanced Entity Relationships Diagram (EER-D)}

Model EER-D berisikan seluruh konsep model ER-D yang ditambah dengan perluasan tentang konsepkonsep dari subclass dan superclass, dan konsep-konsep yang berhubungan yaitu specialization dan generalization. Konsep lainnya yang termasuk dalam model EER-D yaitu Categorization [3] [5] [7] [10]. Bentuk subclass dan superclass merupakan suatu jenis entitas yang akan mempunyai banyak tambahan subgroup entitas yang sangat berarti keberadaannya dan perlu digambarkan secara nyata karena entitas-entitas tersebut penting sekali artinya bagi aplikasi basis data.

Specialization merupakan proses pendefinisian suatu himpunan subclass dari suatu entitas. Entitas ini disebut superclass dari specialization. Himpunan subclass tersebut membentuk specialization yang telah didefinisikan berdasarkan beberapa sifat/karakteristik yang istimewa dari suatu entitas pada suatu superclass yang menggambarkan perbedaan yang jelas di antara entitas tersebut [3]. Generalization adalah proses pendefinisian entitas-entitas yang disatukan menjadi entitas superclass tunggal dari entitas aslinya yang merupakan subclass. Proses generalization dapat dipandang sebagai kebalikan dari proses specialization. Generalization dan specialization dapat digambarkan menggunakan beberapa simbol yang memiliki makna yang sama seperti pada Gambar 3a [3] dan Gambar 3b [7].

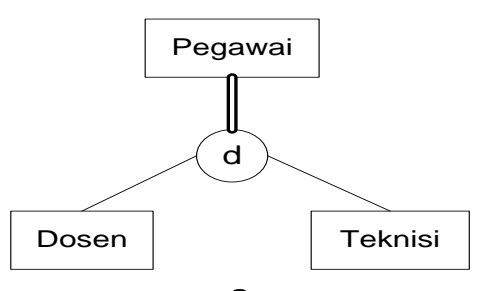

a

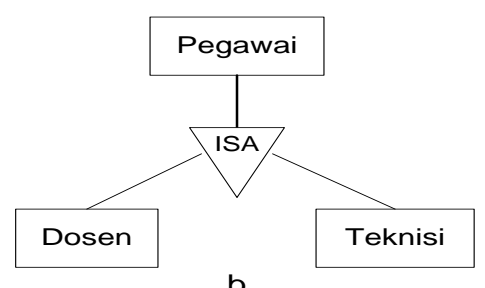

b

Gambar 3. Notasi generalization dan specialization 
Categorization merupakan kebutuhan yang timbul untuk model suatu relasi superclass/subclass tunggal dengan lebih dari satu superclass dimana superclas-superclass tersebut menggambarkan jenis entitas yang berbeda. Setiap entitas yang tergabung dalam superclass maupun subclass sebagai kategori dihubungan dengan simbol union. Contoh penggambaran Categorization disaikan pada Gambar 4.

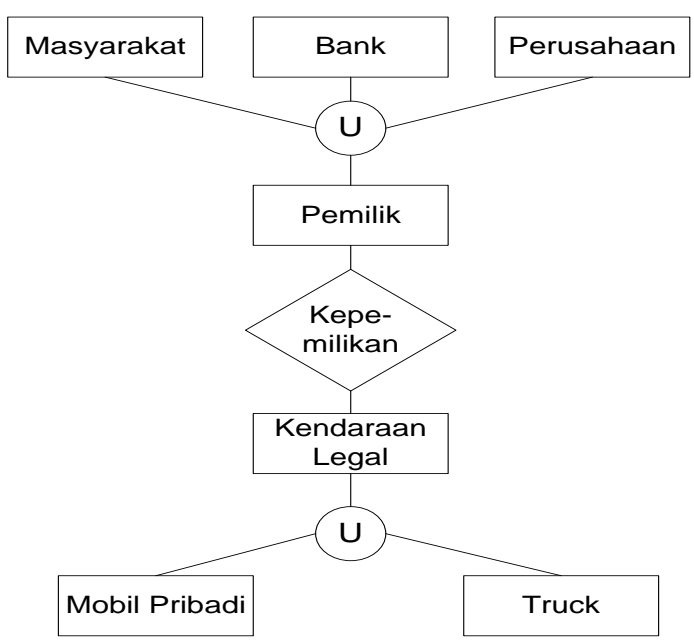

Gambar 4. EER-D Notasi untuk categorization (adaptasi dari [10])

\subsection{Transformasi Menjadi Skema Relasional}

Jika terdapat sebuah entitas Ea dengan atribut masing-masing adalah $\mathrm{AEa}_{1}, \mathrm{AEa}_{2}$, sampai dengan atribut $\mathrm{AEa}_{\mathrm{n}}$, maka bentuk skema relasional dari penggambaran entitas tersebut dapat dirumuskan seperti pada persamaan 1.

$E a=\left(A E a_{1}, A E a_{2}, \ldots, A E a_{n}\right)$

Berdasarkan persamaan 1, jika entitas Ea memiliki atribut kunci AEa1 dan dijadikan sebagai kunci utama (primary key) maka dirumuskan dengan persamaan 2.

$E a=\left(\underline{A E a_{1}}, A E a_{2}, \ldots, A E a_{n}\right)$

Setiap entitas akan membentuk sebuah skema relasional, sedangkan relasi memiliki kemungkinan yang besar untuk menjadi sebuah skema relasional. Jika relasi memiliki atribut sebagai bentuk hasil hubungan relasional dari beberapa entitas, maka harus dibuat sebuah skema relasional. Keterbentukan skema relasional juga tergantung dengan derajat hubungan relasionalnya atau jumlah terbanyak sebuah data dalam suatu entitas dapat berhubungan dengan data dari entitas lain (cardinality constraint) [9]. Jika terdapat hubungan relasional antar entitas dengan derajat relasinya menyatakan 1-to-1, maka untuk ER-D cukup dijadikan sebuah skema relasi, akan tetapi jika relasi tersebut memiliki atribut maka akan terbentuk menjadi 3 (tiga) skema relasional [11]. Gambar 5 akan memperjelas pernyataan tentang ER-D dengan derajat relasi 1-to-1.

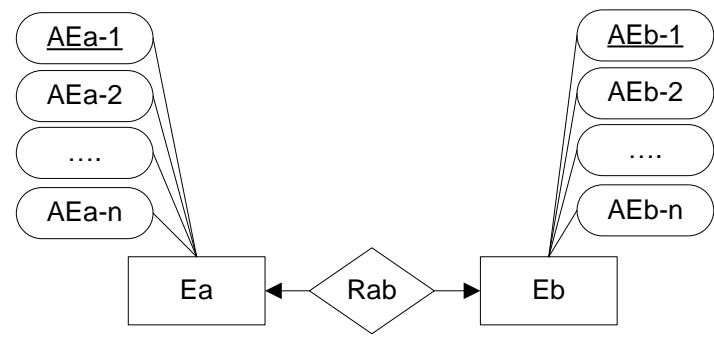

$E a=(\underline{A E a-1, A E b-1}, A E a-2, \ldots, A E a-n, A E b-2, \ldots, A E b-n)$

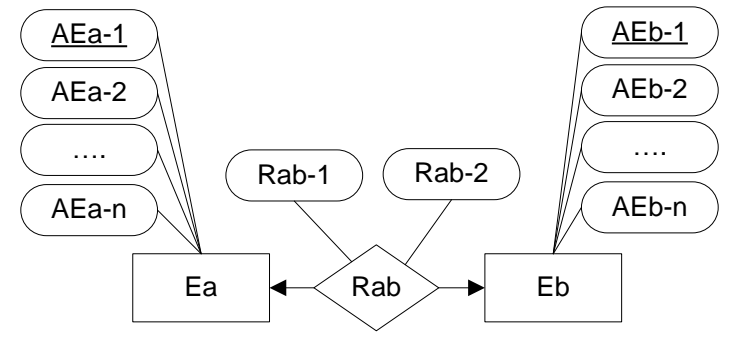

$E a=($ AEa-1, $A E a-2, \ldots, A E a-n)$

$E b=(\underline{A E b-1}, A E b-2, \ldots, A E b-n)$

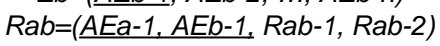

Gambar 5. Transformasi ER-D derajat 1-to-1 menjadi skema relasional 
Jika terdapat relasional antar entitas dengan derajat one-to-many (1-to-N) atau sebaliknya (N-to-1) dengan relasi tidak memiliki atribut, maka akan terbentuk dua (2) skema relasional, dimana entitas yang memilki derajat (many) atau posisi N, maka harus dibubuhkan atribut kunci dari entitas yang memiliki derajat satu (one) sebagai kunci keterhubungan [11]. Tetapi jika relasi dari kedua entitas tersebut memiliki atribut, maka akan dibentuk seperti pada Gambar 5b. Secara grafis hubungan ER-D yang memiliki derajat relasi 1-to-N dijelaskan pada Gambar 6.

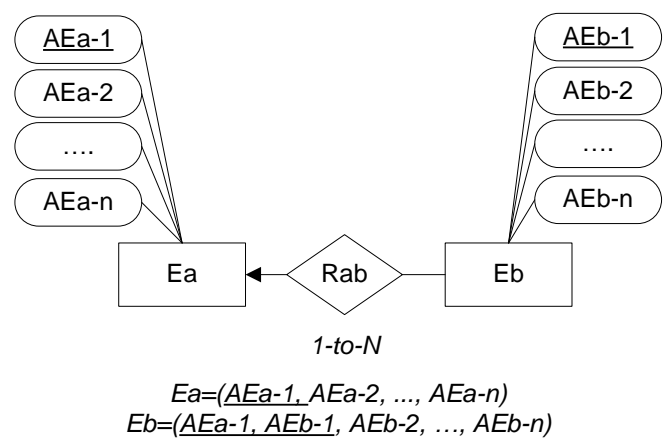

\section{Gambar 6. Transformasi ER-D derajat 1-to-N menjadi skema relasional}

Derajat relasi many-to-many (N-to-M) merupakan hubungan relasional antar entitas dimana setiap anggota atau data dari entitas satu dapat berhubungan dengan banyak data atau anggota pada entitas lain dan demikian juga sebaliknya. Pada hubungan dengan derajat N-to-M ini baik relasinya memiliki atribut maupun tidak tetap akan terbentuk satu skema relasional sebagai tambahan atau skema relasi yang berasal dari relasionships. Transformasi N-to-M dimana relasinya memiliki atribut caranya sama seperti Gambar 5b [11]. Gambar 7 berikut menggambarkan dengan jelas bagaimana hubungan $\mathrm{N}$-to-M ini ditransformasikan menjadi skema relasional.

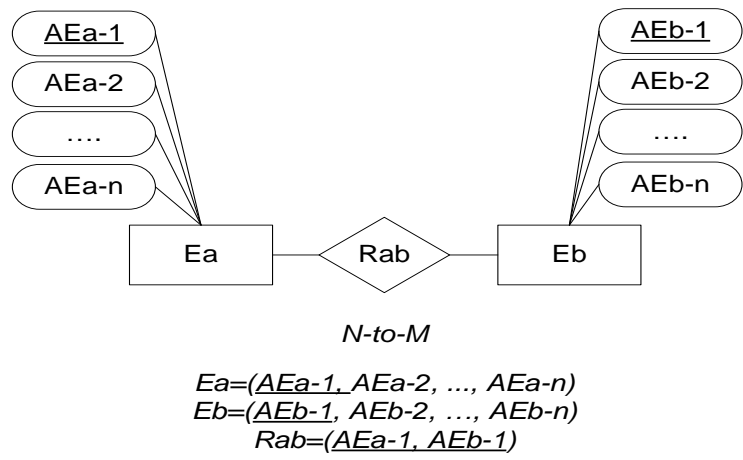

Gambar 7. Transformasi ER-D derajat N-to-M menjadi skema relasional

\section{ANALISIS DAN PEMBAHASAN}

\subsection{Analisa dan Pemodelan Menggunakan ER-D}

Pemodelan data yang dirancang menggunakan teknik ER-D langkah pertama yang dilakukan adalah menentukan entitas-entitas yang ada dalam lingkup sistem. Pada lingkup sistem asistensi terdapat beberapa entitas sebagai penopangnya. Entitas-entitas tersebut terdiri dari Dosen, Mahasiwa, Gedung, Laboran dan Asisten Dosen. Bentuk rancangan basis data relasional menggunakan ER-D lengkap dari sistem asistensi ini disajikan pada Gambar 8.

Setiap entitas dalam lingkup sistem asistensi dapat dijelaskan bahwa entitas dosen adalah seorang pengajar yang mengampu satu atau beberapa mata kuliah. Relasional mengampu ditunjukkan dengan relasi dosen mengajar mata kuliah. Dalam relasi tersebut terdapat atribut yang menjelaskan periode (tahun akademik) mengajar dan kelas apa saja yang diajarnya. Misalnya dosen mengajar mata kuliah yang dibagi menjadi kelas A, kelas B dan seterusnya. 


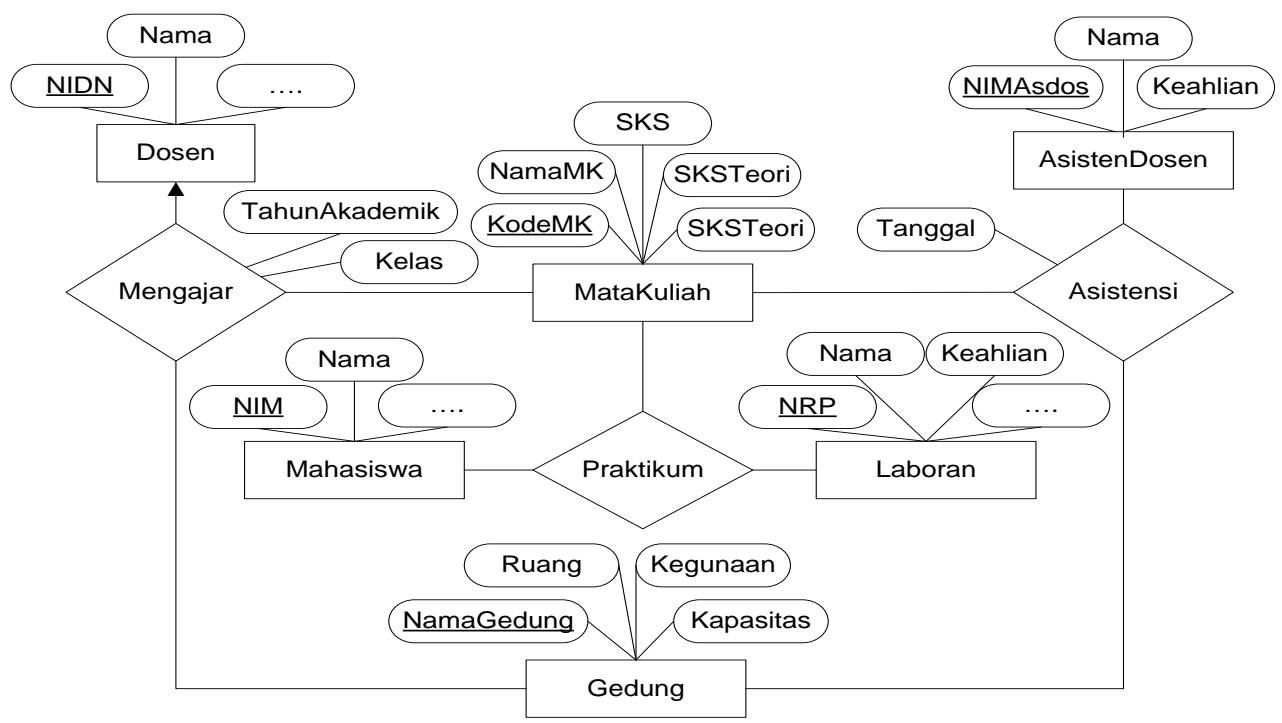

Gambar 8. ER-D sistem asistensi

Berdasarkan Gambar 8 dapat ditransformasikan menjadi skema relasi dengan hasil sebanyak 6 (enam) skema yang berasal dari entitas (nama entitas dibuat tebal) dan 3 (tiga) skema yang berasal dari relasional.

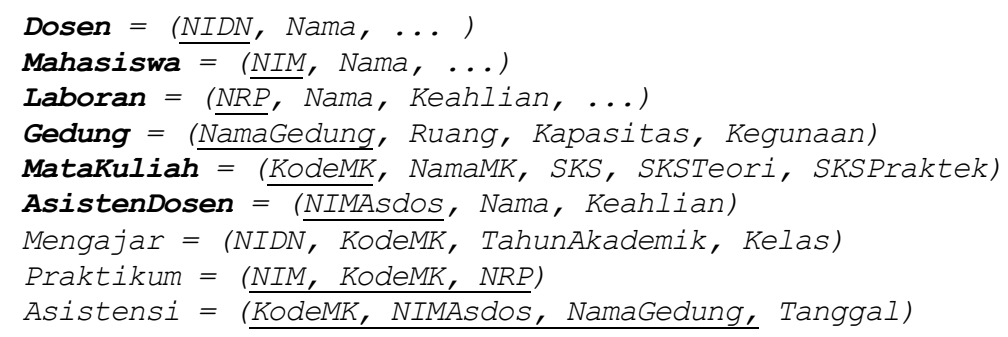

Berdasarkan skema relasional yang terbentuk dari ER-D sistem asistensi perkuliahan praktikum dapat dianalisa bahwa; Jika menginginkan permintaan data tentang jumlah SKS dosen yang mengajar matakuliah praktikum di laboratorium pada suatu gedung tertentu beserta mahasiswa yang menjadi asistennya, maka memerlukan penggabungan (JOIN) antar relasi dari seluruh entitas yang ada. Hal ini akan membuat perintah dalam sintaksis bahasa SQL yang sangat panjang dan memakan waktu yang lama dalam hal proses JOIN tersebut. Hasil ER-D ini masih perlu disederhanakan dan ada juga yang perlu dibuat lebih rinci.

\subsection{Analisa dan Perancangan menggunakan EER-D}

Berdasarkan pada hasil rancangan menggunakan ER-D yang masih belum rinci dan beberapa bagian perlu disederhanakan, maka prinsip-prinsip utama dalam pembuatan ER-D dapat diperluas menggunakan prinsip-prinsip yang ada pada EER-D seperti yang telah dibahas pada sub bagian 2.3 tentang EER-D. Hasil ER-D dianalisa menggunakan pendekatan EER-D dengan prinsip agregasi, generalisasi/spesialisasi dan kategorisasi.

\subsubsection{Analisa Dengan Pendekatan Agregasi}

Pendekatan agregasi merupakan pendekatan dimana jika terdapat relasional yang melibatkan lebih dari 3 (tigas) entitas maka dianggap relasional ketiga entitas tersebut dilakukan terlebih dulu kemudian baru melibatkan entitas berikutnya (karena maksimal jumlah relationship yang dijinkan adalah ternary relationships). Penggambaran entitas beserta atributnya diambil berdasarkan Gambar 8. Bentuk agregasi yang muncul dari sistem asistensi mata kuliah praktikum disajikan pada Gambar 9. 


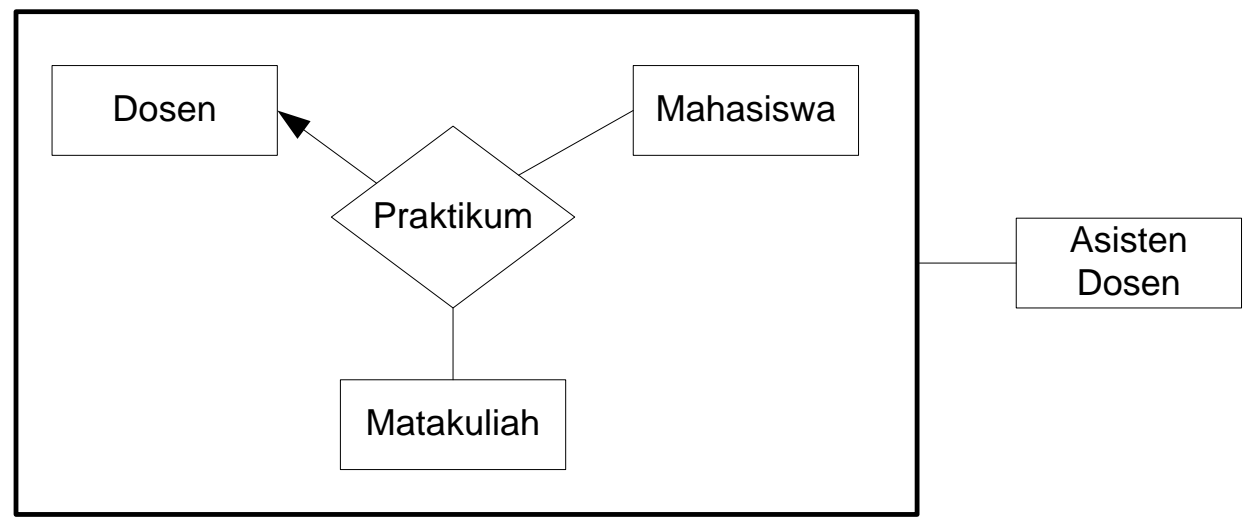

Gambar 9. Bentuk agregasi EER-D sistem asistensi mata kuliah praktikum

Berdasarkan Gambar 9, bentuk agregasi tersebut ditransformasikan menjadi skema relasional akan diperoleh beberapa skema sebagai berikut;

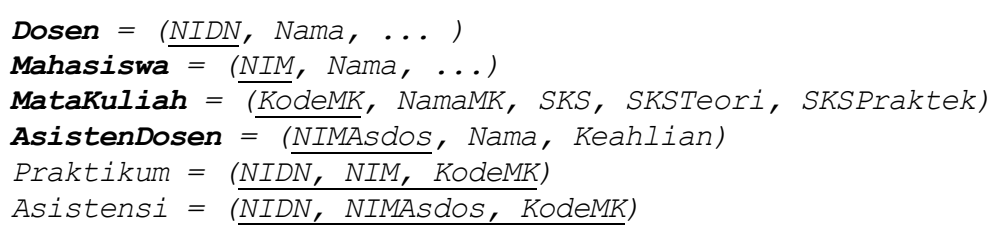

\subsubsection{Analisa Dengan Pendekatan Generalisasi Dan Spesialisasi}

Entitas selain Dosen, Mahasiswa, MataKuliah dan AsistenDosen yang telah disederhanakan menggunakan prinsip agregasi, dapat dibuat lebih rinci menggunan prinsip generalisasi dan spesialisasi. Jika ditinjau dari sudut pandang dari kasus yang digunakan, yaitu yang berhubungan dengan sistem asistensi, maka yang diperhatikan adalah subclass daripada superclass. Untuk lebih jelas disajikan pada Gambar 10.

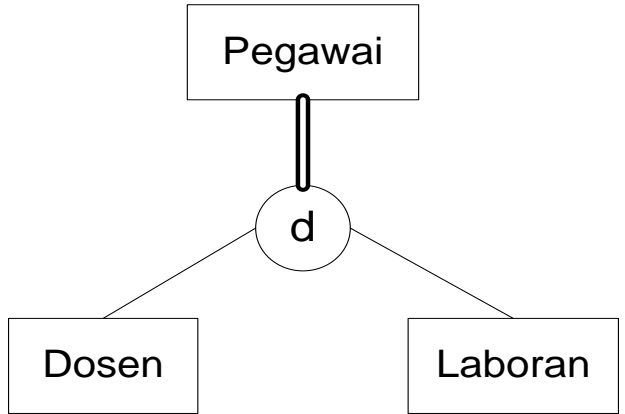

Gambar 10. Spesialisasi dari superclass pegawai menjadi subclass dosen dan laboran

Berdasarkan Gambar 10, yang diperhatikan adalah subclass-nya, maka yang dibuat skema relasinya adalah;

Dosen $=(N I D N$, Nama,$\ldots)$

Laboran $=(\underline{N R P}$, Nama, Keahlian, ...)

Fakta di lapangan entitas mahasiswa dan asisten dosen memiliki kesamaan dalam semua atribut yang dimilki, kecuali terdapat tambahan atribut keahlian bagi asisten dosen. Sedangkan tingkah laku asisten dosen hampir sama dengan dosen pengampu mata kuliah yang diasisteni, terutama dalam hal penyampaian materi mata kuliah, jumlah SKS dan pada jadwal yang sama. Asisten dosen yang memiliki kedua sifat yaitu sebagai turunan dari mahasiswa dan turunan sifat dosen maka dapat digambarkan dalam bentuk pewarisan ganda (multiple inheritance). Pewarisan merupakan salah satu dari bentuk spesialisasi dengan adanya atribut yang diulang (overlapping) atau diturunkan ke entitas lain. Dalam istilah lain dijelaskan dengan superclass dan subclass, dimana atribut dari superclass diturunkan ke subclass-nya. Secara rinci dijelaskan pada Gambar 11, tetapi hal ini tidak akan memunculkan skema relasi baru yang khusus menjelaskan adanya overlapping ini. 


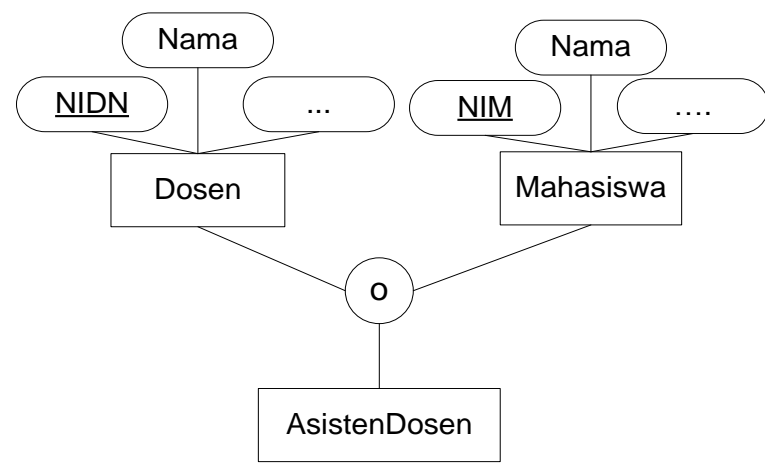

Gambar 11. Pewarisan ganda (multiple inheritance)

\subsubsection{Analisa Menggunakan Pendekatan Kategorisasi}

Beberapa entitas dalam suatu waktu tertentu dapat dijadikan sebagai superclass atau subclass. Superclass disini terdiri dari entitas dosen, mahasiswa dan asisten dosen yang digabungkan (UNION) menjadi entitas Praktikan. Antara entitas Praktikan dengan entitas MataKuliah direlasikan dengan adanya relasi DurasiPraktek. Entitas MataKuliah merupakan superclass yang memiliki dua subclass yaitu entitas MakulTeori dan entitas MakulPraktek. Bentuk EER-D dari pendekatan kategorisasi ini disajikan pada Gambar 12.

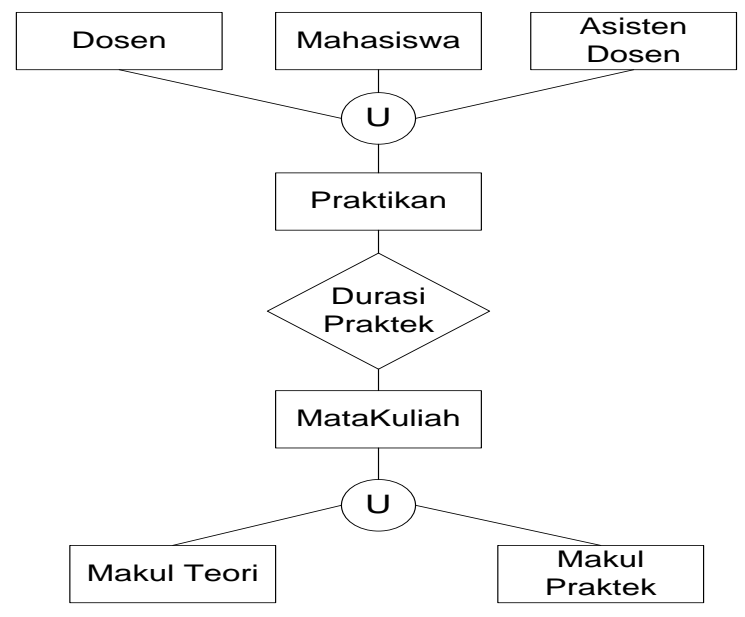

\section{Gambar 12. Kategorisasi dengan gabungan beberapa entitas}

Berdaskan Gambar 12, tranformasi kategorisasi bisa dilakukan cukup entitas yang menjadi superclass karena sudah dapat mewakili entitas yang menjadi subclass. Hasil transformasi EER-D menjadi skema relasional dari pendekatan kategorisasi adalah enitas Praktikan yang berelasi menggunakan DurasiPraktek dengan entitas MataKuliah dengan hasil sebagai berikut;

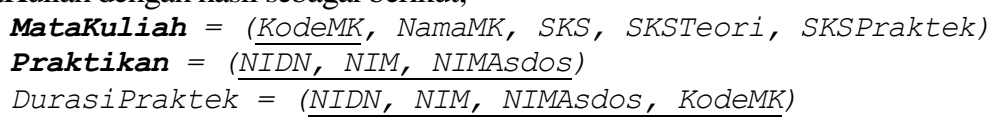

\subsection{Skema Relasional Hasil Analisa dan Pembahasan}

Dari seluruh relasional yang terjadi baik yang berasal dari bentuk ER-D maupun yang telah diperluas atau dikembangkan menjadi EER-D akan tampak saling memberikan kelebihan masing-masing. ER-D memiliki kelebihan kesederhanaan dalam perancangan tetapi sulit menginterpretasikan pada kasus yang sesuai dengan keadaan nyata. Keadaan nyata di lapangan setiap penyelsaian kasus dapat diselesaikan dengan sudut pandang hubungan antar objek, hubungan antar objek hanya dapat dijelaskan dengan pemodelan data dengan pendekatan model class. EER-D mampu melakukan pendekatan yang berorientasi objek yang sangat mirip dengan pendekatan class. Ditinjau dari hasil tranformasi menjadi skema relasional, pendekatan EER-D tercipta skema lebih banyak karena disesuaikan secara rinci perkasus yang dihadapi. Berikut (Tabel 1) skema relasional hasil transformasi secara lengkap dari ER-D dan EER-D. 
Tabel 1. Perbandingan skema relasional Hasil Tranformasi ER-D dan EER-D

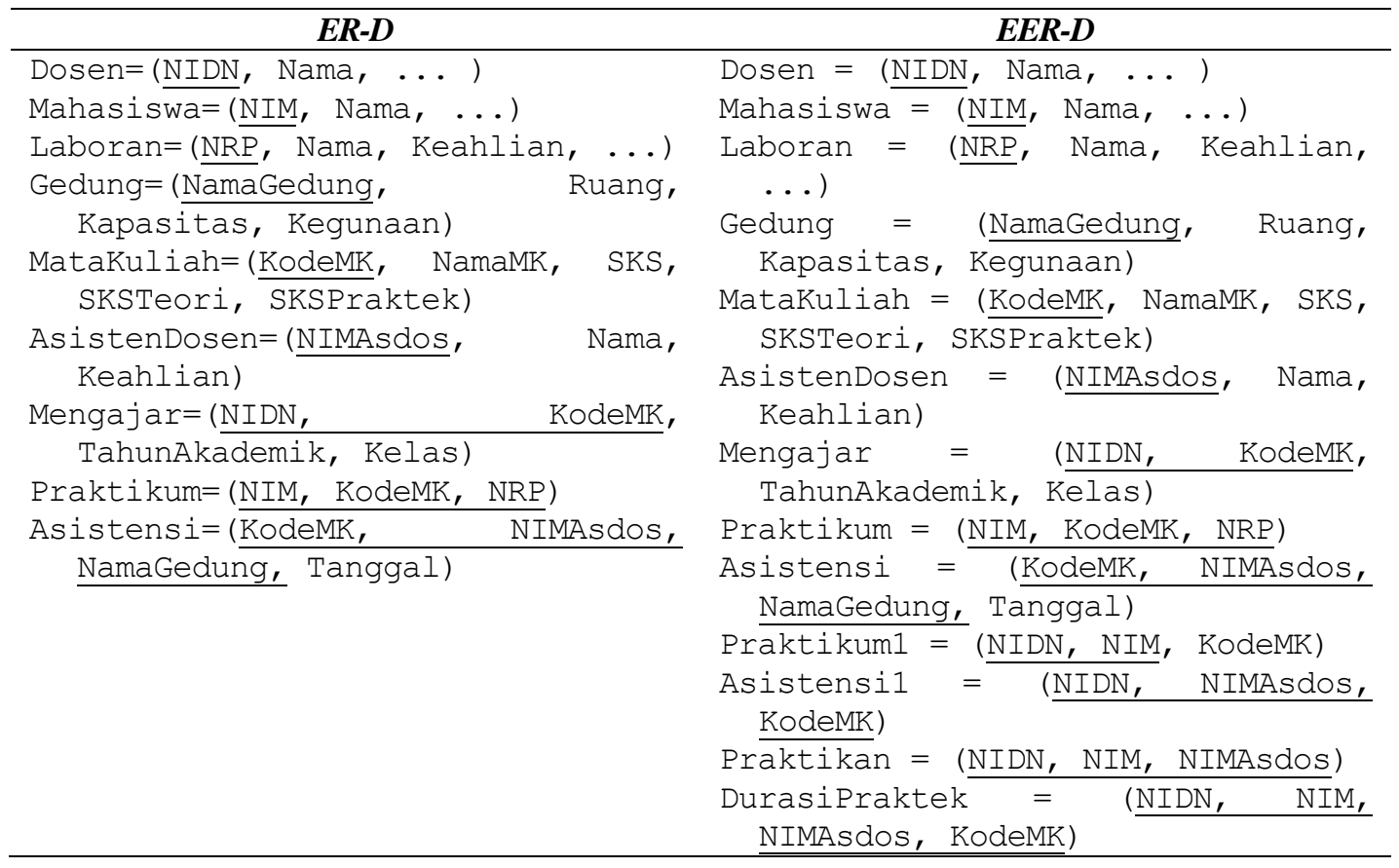

\section{KESIMPULAN}

Pemodelan data dengan merancang basis data menggunakan ER-D lebih sederhana, sifatnya umum tetapi sulit diimplementasikan pada kasus yang orientasinya pada objek. EER-D memiliki keunggulan lebih mendekati pada kasus yang ada di lapangan karena berorientasi pada objek, tetapi karena sifatnya yang harus diselesaikan perkasus memaksa perancangannya lebih rumit dan harus rinci. Pada studi kasus sistem asistensi mata kuliah praktikum ini hasil skema relasi yang ditransformasikan dari EER-D lebih banyak dibandingkan dengan menggunakan ER-D. Skema relasional ini apabila diterapkan ke dalam aplikasi sistem manajemen basis data akan berubah menjadi struktur tabel yang dirangkum dalam sebuah basis data.

\section{DAFTAR PUSTAKA}

[1] (2016, Maret) Kamus Besar Bahasa Indonesia (KBBI). [Online]. http://kbbi.web.id/laboran

[2] DiTDIKTENDIK. (2016, Maret) Pedoman Umum Pemilihan Laboran Berprestasi. Dokumen pdf. [Online]. http://kopertis6.or.id/download/Pedoman\%20Akademisi\%202011/3.\%20pedomanlaboran-berprestasi-firman.pdf

[3] Ramez Elmasri and Shamkant B Navathe, Fundamentals of Database Systems, 4th ed. International: Pearson Addison-Wesley, 2004.

[4] Peter Pin-Shan Chen, "English, Chinese and ER-Diagrams," Data \& Knowledge Engineering, pp. 516, 1997.

[5] Edgar Frank Codd, "A Relational Model of Data for Large Shared Data Banks," Communications of the ACM, vol. 13, no. 6, pp. 377-387, 1970.

[6] Edgar Frank Codd, "The Relational Model for Database Management: Version 2," in Serious Flaws in SQL.: Addison-Wesley, 1990, ch. 23, pp. 371-389.

[7] Abraham Silberschatz, Henry F Korth, and S Sudarshan,. International: McGraw-Hill, 2010, p. 218.

[8] Edgar Frank Codd, Further Normalization of the Data Base Relational Model, May 24-25, 1971.

[9] Fathansyah, Basis Data. Bandung: Informatika, 1999.

[10] Ramez Elmasri and Shamkant B Navathe, "Enhanced Entity-Relationship and UML Modeling," in Fundamentals of Database Systems, 4th ed. International: Pearson Addison-Wesley, 2004, ch. 4, pp. 85-101. 
[11] Ramez Elmasri and Shamkant B Navathe, "Relational Database Design by ER- and EER-toRelational Mapping," in Fundamentals of Database Systems, 4th ed. International: Pearson AddisonWesley, 2004, ch. 7, pp. 193-197. 